A perfect knowledge of the effects of chromosomal abnormalities in domestic animal requires an exact determination of the chromosome involved in each type of translocation as well as of the segregation pattern and the resulting proportion of unbalanced gametes.

From a pratical point of view, the occurate identification by means of new banding methods of the chromosomes involved in each type of abnormality will lead to a better understanding of the meiotic behaviour, the segregation pattern and the consequences on animal production characters.

THE ROLE OF CHROMOSOME DEFECTS AND VARIANTS IN CATTLE BREEDING

\author{
B. MAYR and W. SCHLEGER \\ Institut $f$. Tierzucht und Haustiergentik \\ der Vet.-med. Universität, Linke Bahngasse Ir, I030 Wien Austria
}

Chromosomal polymorphism, in the form of a Robertsonian Translocation $1 / 29$, was detected in 3 out of 280 individuals tested in Austria. The report deals with meiotic findings explaining the tendencies, in cattle, to centric fusions of this naturc.

G-band testing of 50 bulls brought no results as to a new type of polymorphism. Reference is made to 4 bulls with XY/XX complement. No unbalanced complements have so far been observed in this country.

ROUTINE CHROMOSOMAL, EXAMINATION OF AI BUL, IN HUNGARY,

\author{
M. PAPP and A. KOVACS \\ Central Hungavian Station for Artificial \\ Insemination 1440 Budapest 7o, P.O.B. I9, Hungary
}

In Hungary the routine chromosomal examinations started at the beginning of r975. Till now, a total of 324 bulls were karyotypically evaluated in five A. I. stations. $33_{3}$ bulls were found to be normal and II showed chromosomal abnormalities. The bulls belonged to eight pure breeds and three crossed ones. The number of bulls in the breeds examined were as follows: 76 Hungavian Simmental, 2 I Austrian Simmental, 4 German Simmental, I74 HolsteinFriesian, 3 Dutch Friesian, I Swedish Friesian, 7 Limousine, 5 Hereford, I Kostroma and 32 crossbred.

Chromosomal abnormalities were found in the Hungarian Simmental, German Simmental and Holstein-Friesian breeds. In Hungarian Simmental three cases of translocation (two $1 / 29$ and one I 4/2I) and two chimaerisms, in German Simmental one I/29 translocation, in HolsteinFriesian breed one case of mosaic r $3 / 21$ translocation (?) and four chimaerisms were disclosed.

\title{
PRELIMINARY STUdies ON 6 TO 7 DAYS OLD BLASTOCYSTS NON-SURGICALI, RECOVERED FROM CATTLE, III. - METHOD FOR CHROMOSOME PREPARATION
}

\author{
W. A. KING*, T. LINARkS**, J. GUSTAVSSON * and A. BANE** \\ * Dep. of Animal Breeding and Genetics \\ The Swedish University of Agricultural Sciences, \\ S-75007 Uppsala 7. Sweden \\ **Dep. of Obstetrics and Gynaecology, same University
}

A simple technique for making chromosome preparation from 6 to 7 day old bovine blastocysts is described. It is noted that the morphological features of blastocysts and total number of cells greatly influence the quality of the preparation. 